\title{
Development of a Soy-Based Synbiotic Beverage
}

\author{
Suzana Reis Evangelista ${ }^{1}$, Gislaine Ghiselli ${ }^{2}$, Francisco Maugeri Filho ${ }^{2}$ \\ ${ }^{1}$ Departamento de Ciência dos Alimentos, Universidade Federal de Lavras, Lavras, Brasil; ${ }^{2}$ Departamento de Engenharia de Alimen- \\ tos, Faculdade de Engenharia de Alimentos, Universidade Estadual de Campinas, Campinas, Brasil. \\ Email:suzanak@hotmail.com
}

Received May $15^{\text {th }}, 2012$; revised July $3^{\text {rd }}, 2012$; accepted July $10^{\text {th }}, 2012$

\begin{abstract}
Nowadays consumers seek foods that not only provide basic nutrition but also contain compounds that contribute to health. Thus, different products have been designed to meet this demand, especially those with probiotic and prebiotic characteristics. This study aimed to evaluate different formulations of a soy-based synbiotic beverage. The composition and process conditions were defined using a Placket \& Burman factorial design in which the independent variables were process temperature, concentrations of the soy hydrosoluble extract and fructooligosaccharides (FOS) and the initial concentration of the probiotics Bifidobaterium longum, Lactobacillus acidophilus, Lactobacillus paracasei subsp. paracasei, Lactobacillus rhamnosus. Changes to the product by addition of sucrose, Streptococcus thermophilus and Lactobacillus delbrueckii subsp. bulgaricus were also studied. Response parameters were: $\mathrm{pH}$, cell concentration (plate counting), and quantification of fructooligosaccharides, acetic acid and lactic acid. The specific growth rate $\left(\mu_{\mathrm{x}}\right)$ and change in cell count $(\Delta \mathrm{x})$ were determined in each formulation. The soybean hydrosoluble extract was considered a good substrate for beverage production; FOS had a greater effect at lower concentrations. At the end of all fermentation tests the total probiotic count was greater than $7 \log \mathrm{CFU} / \mathrm{mL}$, meeting the legal requirements of a functional food. Lower temperatures were better for the growth of probiotics. The addition of sucrose resulted in a lower consumption of FOS by the fermenting microorganisms, while the presence of Streptococcus thermophilus and Lactobacillus delbrueckii subsp. bulgaricus represented little change concerning the evaluated characteristics. Therefore, according to the results of this study, the production of a soy-based symbiotic fermented beverage can be performed using soybean hydrosoluble extract at $10 \%(\mathrm{w} / \mathrm{v})$, fructooligosaccharides at about $3 \%(\mathrm{w} / \mathrm{v})$, sucrose at $12 \%(\mathrm{w} / \mathrm{v})$, and the process temperature should be maintained at $35^{\circ} \mathrm{C}$. Initial probiotic concentrations need not exceed $5 \times 10^{6} \mathrm{CFU} / \mathrm{ml}$.
\end{abstract}

Keywords: Probiotics; Prebiotics; Soy; Synbiotic Beverage; Functional Food

\section{Introduction}

Interest in functional foods has recently increased among consumers due to a greater consciousness of health and nutrition, as well as the need to prevent rather than cure diseases and also the increasing scientific evidences of their effectiveness [1].

The concept of functional foods originated in Japan in the mid-1980's, defined as being similar in appearance to conventional foods and used as part of a normal diet, but demonstrating nutritional functions beyond those considered basic, physiological benefits or reducing the chronic risk of disease, known as Food for Specified Health Use (FOSHU) [2]. Thus, food products containing probiotics and prebiotics are considered functional.

Recent works have reported the evaluation of probiotic and prebiotic supplemented foods, in which fructooligosaccharides, Bifidobaterium and Lactobacillus are those most utilized [3-6]. Most research has focused on evaluating the addition of probiotics and prebiotics, obtaining a product with a better final quality known as synbiotic food $[7,8]$. However, for better bacterial fixing and proliferation in the intestine, as well as better synergistic effect, the selection of microorganism strains with improved ability to use a particular prebiotic is important [9].

Soy consumption provides many health benefits due to the presence of beneficial compounds such as isoflavones. Interest in soy-based products has been steadily increaseing and new products are being developed [10].

Soy hydrosoluble extracts have been studied for the production of synbiotic beverages and present an excellent method for the cultivation of probiotics, but process conditions must be optimized to maintain product quality [11].

The addition of sucrose to soy-based fermented foods was also studied by some authors, who reported a better sensorial acceptance as well as positive changes to the product, including a more pronounced decrease in $\mathrm{pH}$, 
lower syneresis and increased viability of bifidobacteria $[11,12]$.

Among the many potential lactic bacteria, Streptococcus thermophilus and Lactobacillus bulgaricus are most traditionally utilized, since they result in rapid acidification of the medium through the production of organic acids, especially lactic acid, and produce other compounds such as acetic acid, ethanol, aromatic hydrocarbons, exopolysaccharides and many enzymes of great importance. They also act to increase shelf life, improveing texture, and contribute to a pleasant sensory profile of the final product [13], including probiotic bacteria that may be used in co-culture $[14,15]$.

Thus, based on the above information the present study aimed to evaluate the production of a synbiotic beverage composed of soy hydrosoluble extract, fructooligosaccharides as prebiotic, Bifidobaterium longum, Lactobacillus acidophilus, Lactobacillus paracasei subsp. Paracasei and Lactobacillus rhamnosus as probiotic microoganisms, varying concentrations and the fermentation temperature, including the addition of sucrose and the conventional yogurt lactic bacteria Streptococcus thermophilus and Lactobacillus delbrueckii subsp. bulgaricus.

\section{Material and Methods}

\subsection{Material}

Soy hydrosoluble extract was purchased from Organic Provesol PSA-Brazil, soy lecithin used as an antifoaming agent from Doremus-Brazil, fructooligosaccharides (FOS) as prebiotic (Raftilose $95^{\circledR}$ ) from Orafti-Belgium and sucrose from Synth-Brazil.

\subsection{Cultures}

The microorganisms Bifidobacterium longum BL04, Lactobacillus acidophilus LAC4, Lactobacillus paracasei subsp. paracasei LBC81, Lactobacillus rhamnosus LR32, Streptococcus thermophilus TA40 and Lactobacillus delbrueckii subsp. bulgaricus LB340) were kindly provided by Danisco-Brazil as freeze-dried cells in sealed packages.

\subsection{Cell Culture Methodology}

\subsubsection{Preparation of Inoculum}

The inocula were prepared by the aseptically weighing and transferring the freeze-dried cultures to vials containing $6 \%(\mathrm{w} / \mathrm{v})$ soy hydrosoluble extract, incubated for 30 minutes at $37^{\circ} \mathrm{C}$, and subsequently frozen at $-18^{\circ} \mathrm{C}$.

\subsubsection{Fermentation}

The fermentations were carried out in closed $50 \mathrm{~mL}$ vials, in an oxygen-restricted environment containing $30 \mathrm{~mL}$ of material to be fermented, previously pasteurized at $116^{\circ} \mathrm{C}$ for 4 minutes and rapidly cooled to room temperature [16]. The fermentations lasted until reaching $\mathrm{pH}$ values close to 5. Samples were taken periodically for analysis of $\mathrm{pH}$, counting of probiotics, and determination of acetic and lactic acids.

An experimental design was first carried out in order to evaluate the effect of some variables: inoculum concentration, medium composition and process temperature, and the responses were probiotic count and $\mathrm{pH}$. Thereafter, the most significant variables from the first factorial design were selected and further tests were performed with the addition of sucrose and conventional yogurt microorganisms. A Plackett \& Burman experimental design was used, with 12 trials and three central points, totalling 15 trials [17] with seven independent variables: concentration of soy hydrosoluble extract, fructooligosaccharide concentration, temperature, initial count of L. acidophilus, L. paracasei, L. rhamnosus and B. longum. Table 1 shows the conditions of the tests with coded and real variables.

After accomplishing this step, additional assays were performed varying the concentration of sucrose and adding Streptococcus thermophilus and Lactobacillus bulgaricus (Table 2), which were conducted at the following conditions: temperature $35^{\circ} \mathrm{C}, 10 \%(\mathrm{w} / \mathrm{v})$ soy hydrosoluble extract, $3 \%(\mathrm{w} / \mathrm{v})$ fructooligosaccharides, $5.5 \times 10^{6}$ $\mathrm{CFU} / \mathrm{mL}$ of L. acidophilus, L. rhamnosus and B. longum and $1 \times 10^{6} \mathrm{CFU} / \mathrm{mL}$ of $L$. paracasei.

\subsection{Analytical Methods}

\subsubsection{CFU Counting and Microbial Growth}

Aliquots of $1 \mathrm{~mL}$ were transferred to tubes containing 9 $\mathrm{mL}$ of peptone water $(0.1 \%)$. CFU counting was carried out in depth in MRS Agar with $0.01 \%$ aniline blue, and incubated for $72 \mathrm{~h}$ at $37^{\circ} \mathrm{C}$ in aerobic and anaerobic conditions [11].

The specific growth rates $\left(\mu_{\mathrm{x}}\right)$ were calculated from the angular coefficient of the fitted line for Ln cell count (X) versus fermentation time [18]. The change in the number of cells $(\Delta x)$ was calculated by the difference between final and initial cell number.

\subsubsection{Frutooligosaccharide Determination}

Prior to fructooligosaccharide analysis, cells and proteins were removed from the medium by adding $0.01 \mathrm{~mL}$ of citric acid $1 \mathrm{M}$ to $1.0 \mathrm{~mL}$ of the sample, followed by centrifugation at $9640 \mathrm{~g}$ for $10 \mathrm{~min}$ at $5^{\circ} \mathrm{C}$. The supernatant was diluted in deionized water and filtered through a $0.22 \mu \mathrm{m}$ filter [16]. Samples were identified and quantified by ion chromatography (HPLC-PAD), using a Dionex DX-500 system (Sunnyvale, CA, USA) consisting of a GP50 gradient pump, an ED-40 electrochemical detector operating in the amperometric pulse mode (gold electrode 
Table 1. Coded variables and real values (in brackets) of the Placket \& Burman design.

\begin{tabular}{|c|c|c|c|c|c|c|c|}
\hline \multirow[b]{2}{*}{ Assay } & \multicolumn{7}{|c|}{ Independent variables } \\
\hline & $\operatorname{SHE}^{*}(\%)(w / v)$ & FOS $(\%)(w / v)$ & Temp. $\left({ }^{\circ} \mathrm{C}\right)$ & $\begin{array}{l}\text { L. acidophilus } \\
\text { (CFU/mL) }\end{array}$ & $\begin{array}{l}\text { L. paracasei } \\
(\mathrm{CFU} / \mathrm{mL})\end{array}$ & $\begin{array}{l}\text { L. rhamnosus } \\
\text { (CFU/mL) }\end{array}$ & $\begin{array}{l}\text { B. longum } \\
\text { (UFC } / \mathrm{mL})\end{array}$ \\
\hline 1 & $1(10)$ & $-1(3)$ & $1(40)$ & $-1\left(1 \times 10^{6}\right)$ & $-1\left(1 \times 10^{6}\right)$ & $-1\left(1 \times 10^{6}\right)$ & $1\left(1 \times 10^{7}\right)$ \\
\hline 2 & $1(10)$ & $1(5)$ & $-1(34)$ & $1\left(1 \times 10^{7}\right)$ & $-1\left(1 \times 10^{6}\right)$ & $-1\left(1 \times 10^{6}\right)$ & $-1\left(1 \times 10^{6}\right)$ \\
\hline 3 & $-1(4)$ & $1(5)$ & $1(40)$ & $-1\left(1 \times 10^{6}\right)$ & $1\left(1 \times 10^{7}\right)$ & $-1\left(1 \times 10^{6}\right)$ & $-1\left(1 \times 10^{6}\right)$ \\
\hline 4 & $1(10)$ & $-1(3)$ & $1(40)$ & $1\left(1 \times 10^{7}\right)$ & $-1\left(1 \times 10^{6}\right)$ & $1\left(1 \times 10^{7}\right)$ & $-1\left(1 \times 10^{6}\right)$ \\
\hline 5 & $1(10)$ & $1(5)$ & $-1(34)$ & $1\left(1 \times 10^{7}\right)$ & $1\left(1 \times 10^{7}\right)$ & $-1\left(1 \times 10^{6}\right)$ & $1\left(1 \times 10^{7}\right)$ \\
\hline 6 & $1(10)$ & $1(5)$ & $1(40)$ & $-1\left(1 \times 10^{6}\right)$ & $1\left(1 \times 10^{7}\right)$ & $1\left(1 \times 10^{7}\right)$ & $-1\left(1 \times 10^{6}\right)$ \\
\hline 7 & $-1(4)$ & $1(5)$ & $1(40)$ & $1\left(1 \times 10^{7}\right)$ & $-1\left(1 \times 10^{6}\right)$ & $1\left(1 \times 10^{7}\right)$ & $1\left(1 \times 10^{7}\right)$ \\
\hline 8 & $-1(4)$ & $-1(3)$ & $1(40)$ & $1\left(1 \times 10^{7}\right)$ & $1\left(1 \times 10^{7}\right)$ & $-1\left(1 \times 10^{6}\right)$ & $1\left(1 \times 10^{7}\right)$ \\
\hline 9 & $-1(4)$ & $-1(3)$ & $-1(34)$ & $1\left(1 \times 10^{7}\right)$ & $1\left(1 \times 10^{7}\right)$ & $1\left(1 \times 10^{7}\right)$ & $-1\left(1 \times 10^{6}\right)$ \\
\hline 10 & $1(10)$ & $-1(3)$ & $-1(34)$ & $-1\left(1 \times 10^{6}\right)$ & $1\left(1 \times 10^{7}\right)$ & $1\left(1 \times 10^{7}\right)$ & $1\left(1 \times 10^{7}\right)$ \\
\hline 11 & $-1(4)$ & $1(5)$ & $-1(34)$ & $-1\left(1 \times 10^{6}\right)$ & $-1\left(1 \times 10^{6}\right)$ & $1\left(1 \times 10^{7}\right)$ & $1\left(1 \times 10^{7}\right)$ \\
\hline 12 & $-1(4)$ & $-1(3)$ & $-1(34)$ & $-1\left(1 \times 10^{6}\right)$ & $-1\left(1 \times 10^{6}\right)$ & $-1\left(1 \times 10^{6}\right)$ & $-1\left(1 \times 10^{6}\right)$ \\
\hline 13 & $0(7)$ & $0(4)$ & $0(37)$ & $0\left(5.5 \times 10^{6}\right)$ & $0\left(5.5 \times 10^{6}\right)$ & $0\left(5.5 \times 10^{6}\right)$ & $0\left(5.5 \times 10^{6}\right)$ \\
\hline 14 & $0(7)$ & $0(4)$ & $0(37)$ & $0\left(5.5 \times 10^{6}\right)$ & $0\left(5.5 \times 10^{6}\right)$ & $0\left(5.5 \times 10^{6}\right)$ & $0\left(5.5 \times 10^{6}\right)$ \\
\hline 15 & $0(7)$ & $0(4)$ & $0(37)$ & $0\left(5.5 \times 10^{6}\right)$ & $0\left(5.5 \times 10^{6}\right)$ & $0\left(5.5 \times 10^{6}\right)$ & $0\left(5.5 \times 10^{6}\right)$ \\
\hline
\end{tabular}

*Soy hydrosoluble extract.

Table 2. Inoculum and sucrose concentrations used in the additional assays of the fermented beverage* .

\begin{tabular}{cccc}
\hline Assay & Sac. (\%) (w/v) & ST (CFU/mL) & LB $(\mathrm{CFU} / \mathrm{mL})$ \\
\hline 1 & 0 & 0 & 0 \\
2 & 12 & 0 & 0 \\
3 & 0 & 0 & $1 \times 10^{6}$ \\
4 & 0 & $1 \times 10^{6}$ & 0 \\
5 & 0 & $1 \times 10^{6}$ & $1 \times 10^{6}$ \\
6 & 12 & 0 & $1 \times 10^{6}$ \\
7 & 12 & $1 \times 10^{6}$ & 0 \\
8 & 12 & $1 \times 10^{6}$ & $1 \times 10^{6}$ \\
\hline
\end{tabular}

*Sac: sucrose; ST: Streptococcus thermophilus; LB: Lactobacillus bulgaricus.

and $\mathrm{Ag}-\mathrm{AgCl}$ reference electrode). A CarboPac PA 100 column $(240 \times 4 \mathrm{~mm})$ and PA100 CarboPac precolumn $(50 \times 4 \mathrm{~mm})$ were used. Elution was performed at 1 $\mathrm{mL} \cdot \mathrm{min}^{-1}$ with a $\mathrm{NaOH}$ solution $(100 \mathrm{mM})$ in a linear gradient of sodium acetate $(0-500 \mathrm{mM})$. The standard curve was constructed with pure standards of kestose, nystose and 1-fructosilnystose (Wako Pure Chemical
Industries, Ltd.), glucose, fructose and sucrose (Merck). Identification and quantification of sugars were performed respectively by means of the retention time (tR) and external standardization with injection of at least 7 points in different concentrations of chromatographic standard grade sugars [19].

\subsubsection{Determination of Acetic and Lactic Acids}

Samples were prepared according to the methodology proposed by Donkor et al. [5] with some modifications: $0.2 \mathrm{~mL}$ of nitric acid $15.5 \mathrm{M}$ and $2 \mathrm{~mL}$ of deionised water were added to $6 \mathrm{ml}$ samples and this mixture was centrifuged at $785 \times \mathrm{g}$ for 20 minutes to remove cells and proteins. Subsequently, the supernatant was filtered through $0.22 \mu \mathrm{m}$ filters, diluted and analyzed by high performance liquid chromatography (HPLC). The liquid chromatograph system consisted of a Varian model 9010, with auto-sampler, column oven, ternary pump and UVVis detector. The mobile phase consisted of an aqueous solution of sulfuric acid, $\mathrm{pH}$ 2.60. Elution was isocratic with a mobile phase flow rate of $0.6 \mathrm{~mL} / \mathrm{min}$ through an Aminex HPX-87H (BioRad) ion exchange column and pre-column, at $35^{\circ} \mathrm{C}$. The detection of compounds was performed using a UV-Vis Detector at $204 \mathrm{~nm}$. Total analysis time was 20 minutes [20]. 


\section{Results and Discussion}

\subsection{Plackett \& Burman Experimental Design}

Results of the experiments are shown in Table 3. It can be observed that the initial $\mathrm{pH}$ values ranging from approximately 6.0 to 6.5 decreased during fermentation, and after 6 hours some experiments presented a pH below 5 . At this point the bottles were taken from the incubator and frozen at $-20^{\circ} \mathrm{C}$. Fermentations were concluded at $\mathrm{pH} 5$ since at this point samples had already obtained a firm consistency.

The total probiotics count in functional products is regulated by federal law and states that the minimum number of viable probiotics must be between $10^{8}$ and $10^{9}$ CFU per daily serving ready for consumption [21]; the lowest value obtained in the experiments was $7.25 \mathrm{log}$ $\mathrm{CFU} / \mathrm{mL}$, where $10 \mathrm{ml}$ of the product can meet the minimum requirements. With respect to the results for $\mu_{\mathrm{x}}$ and $\Delta x$, some values are missing in the table due to difficulties in the plating method, which led to considerable data variability in some cases, despite repetitions. This can be observed from the results of the central point (experiments 13 to 15 ), which presented substantial variation.

Results were analysed using the software STATISTICA 8.0 [22] and are shown in Tables 4 and 5.

As can be seen in Table 4, the variables with significant effect at $90 \%$ confidence in which $\mathrm{pH}$ the response are the initial SHE, L. paracasei and L. acidophilus concentrations and fermentation temperature. The SHE had a positive significant effect on $\mathrm{pH}$ for all fermentation times as can be expected, since it has a $\mathrm{pH}$ around 6.8 , a good buffering effect and is the main beverage constituent. Thus, the higher the SHE concentration, the higher the buffer effect and $\mathrm{pH}$.

Temperature has negative effect on $\mathrm{pH}$, i.e., $\mathrm{pH}$ falls faster as the temperature increases, due to microbial growth. Regarding the influence caused by microorganisms, only L. acidophilus and L. paracasei negatively influenced $\mathrm{pH}$, where for L. paracasei this influence occurred during the entire fermentation. The same did not occur with L. acidophilus, which influence $\mathrm{pH}$ only at the end of the fermentation period. This negative effect on $\mathrm{pH}$ is due to the fact that during growth of the probiotic microorganisms sugars from either soybean or FOS are consumed, resulting in production of acetic and lactic acids [23] causing a decrease in $\mathrm{pH}$. This process is most intensive with $L$. paracasei and L. acidophilus.

Concerning the data in Table 5, it can be seen that the initial concentrations of SHE and FOS had a significant effect on the final cell count, which were positive for SHE and negative for FOS.

Therefore, the higher the SHE concentration, higher

Table 3. Placket \& Burman design results.

\begin{tabular}{|c|c|c|c|c|c|c|c|c|c|c|}
\hline \multirow{2}{*}{ Experiments } & \multicolumn{6}{|c|}{$\mathrm{pH}$} & \multirow{2}{*}{$\begin{array}{c}\begin{array}{c}\mathrm{FCFU} \\
(\log \mathrm{CFU} / \mathrm{mL})\end{array} \\
\mathrm{CT}\end{array}$} & \multirow{2}{*}{$\frac{\mu_{\mathrm{x}}\left(\mathrm{h}^{-1}\right)}{\mathrm{CT}}$} & \multicolumn{2}{|c|}{$\Delta \mathrm{x}(\log \mathrm{CFU} / \mathrm{mL})$} \\
\hline & $0 \mathrm{~h}$ & $2 \mathrm{~h}$ & $4 \mathrm{~h}$ & $6 \mathrm{~h}$ & $8 \mathrm{~h}$ & $10 \mathrm{~h}$ & & & $\mathrm{LC}$ & $\mathrm{BL}$ \\
\hline 1 & 6.5 & 6.4 & 6.2 & 5.7 & 5.0 & - & 8.65 & 0.45 & 0.70 & 1.73 \\
\hline 2 & 6.5 & 6.4 & 6.3 & 6.0 & 5.6 & 5.1 & 8.32 & 0.30 & 0.60 & 0.09 \\
\hline 3 & 6.0 & 5.8 & 5.3 & 4.8 & - & - & 7.40 & - & - & - \\
\hline 4 & 6.5 & 6.3 & 6.0 & 5.3 & 4.9 & - & 8.22 & 0.26 & 0.71 & 1.31 \\
\hline 5 & 6.2 & 6.0 & 5.9 & 5.6 & 5.2 & 4.8 & 8.36 & 0.28 & 0.50 & 0.64 \\
\hline 6 & 6.1 & 5.9 & 5.4 & 4.9 & - & - & 7.96 & 0.20 & 0.55 & - \\
\hline 7 & 6.5 & 6.3 & 5.8 & 5.0 & - & - & 7.25 & 0.20 & 0.59 & 0.73 \\
\hline 8 & 6.0 & 5.7 & 5.1 & 4.4 & - & - & 7.88 & 0.07 & 0.03 & 0.45 \\
\hline 9 & 6.0 & 5.9 & 5.8 & 5.4 & 5.0 & - & 8.03 & 0.26 & 0.35 & 0.10 \\
\hline 10 & 6.1 & 6.1 & 5.9 & 5.7 & 5.5 & 5.1 & 8.29 & 0.40 & 0.83 & 0.18 \\
\hline 11 & 6.5 & 6.4 & 6.3 & 6.1 & 5.7 & 5.1 & 7.50 & 0.07 & 0.43 & 0.09 \\
\hline 12 & 6.5 & 6.4 & 6.4 & 6.2 & 5.7 & 5.1 & 7.77 & 0.40 & 1.10 & - \\
\hline 13 & 6.3 & 6.2 & 5.9 & 5.5 & 4.9 & - & 8.24 & 0.48 & 0.62 & 0.73 \\
\hline 14 & 6.2 & 6.1 & 5.8 & 5.3 & 5.1 & - & 7.89 & 0.40 & 0.19 & 0.42 \\
\hline 15 & 6.2 & 6.1 & 5.7 & 5.2 & 5.1 & - & 8.01 & 0.10 & 0.41 & 0.71 \\
\hline
\end{tabular}

*FCFU: Final colony forming units; LC: Lactobacillus spp.; BL: Bifidobaterium logum. 
Table 4. Main effects of variable estimates on $\mathrm{pH}$ during fermentation of SHE in the Plackett \& Burman experimenttal design.

\begin{tabular}{lcccc}
\hline \multicolumn{5}{c}{ Estimated effects for $\mathrm{pH}$} \\
\hline \multicolumn{1}{c}{ Independent variables } & $0 \mathrm{~h}$ & $2 \mathrm{~h}$ & $4 \mathrm{~h}$ & $6 \mathrm{~h}$ \\
\hline $\mathrm{R}^{2}$ & 0.9834 & 0.9796 & 0.9618 & 0.9255 \\
Average & $\mathbf{6 . 2 8 8}$ & $\mathbf{6 . 1 5 6}$ & $\mathbf{5 . 8 7 0}$ & $\mathbf{5 . 4 3 9}$ \\
Curvature & -0.082 & -0.078 & -0.113 & -0.152 \\
$\mathrm{X} 1$ : SHE $(\%)$ & $\mathbf{0 . 0 7 2}$ & $\mathbf{0 . 0 8 2}$ & $\mathbf{0 . 1 6 3}$ & $\mathbf{0 . 1 9 5}$ \\
X2: FOS $(\%)$ & 0.018 & -0.008 & -0.047 & -0.032 \\
X3: Temperature $\left({ }^{\circ} \mathrm{C}\right)$ & -0.035 & $-\mathbf{0 . 1 3 2}$ & $-\mathbf{0 . 4 7 0}$ & $-\mathbf{0 . 8 0 8}$ \\
X4: L. acidophilus $(\mathrm{UFC} / \mathrm{mL})$ & -0.015 & -0.052 & -0.117 & $\mathbf{- 0 . 2 8 5}$ \\
X5: L. paracasei $(\mathrm{UFC} / \mathrm{mL})$ & $-\mathbf{0 . 4 0 5}$ & $-\mathbf{0 . 4 8 8}$ & $\mathbf{- 0 . 6 2 7}$ & $\mathbf{- 0 . 5 6 8}$ \\
X6: L. rhamnosus $(\mathrm{UFC} / \mathrm{mL})$ & 0.015 & 0.035 & 0.020 & -0.045 \\
X7: B. longum $(\mathrm{UFC} / \mathrm{mL})$ & 0.018 & 0.025 & 0.023 & 0.015 \\
\hline
\end{tabular}

*Variables in bold have a significant effect $(\mathrm{p}<0.10)$.

Table 5. Main effect of variable estimates on the final CFU $(\log \mathrm{CFU} / \mathrm{mL}), \mu_{\mathrm{x}}\left(\mathrm{h}^{-1}\right)$ and $\Delta x(\log \mathrm{CFU} / \mathrm{mL})$ during fermentation of SHE.

\begin{tabular}{lcccc}
\hline \multicolumn{1}{c}{ Independent variables } & FCFU & $\mu_{\mathrm{x}}$ & $\Delta \mathrm{x}(\mathrm{LC})$ & $\Delta \mathrm{x}(\mathrm{BL})$ \\
\hline $\mathrm{R}^{2}$ & 0.8984 & 0.5674 & 0.6552 & 0.6807 \\
Average & $\mathbf{7 . 9 6 8}$ & $\mathbf{0 . 2 2 9}$ & $\mathbf{0 . 4 0 7}$ & $\mathbf{0 . 4 7 8}$ \\
Curvature & 0.155 & -0.043 & -0.163 & -0.220 \\
$\mathrm{X} 1$ : SHE $(\%)$ & $\mathbf{0 . 6 6 1}$ & 0.178 & 0.405 & $\mathbf{0 . 6 7 4}$ \\
$\mathrm{X}$ : FOS $(\%)$ & $-\mathbf{0 . 3 4 1}$ & -0.158 & -0.394 & $\mathbf{- 0 . 5 0 5}$ \\
X3: Temperature $\left({ }^{\circ} \mathrm{C}\right)$ & -0.152 & -0.115 & 0.496 & -0.144 \\
X4: L. acidophilus $(\mathrm{UFC} / \mathrm{mL})$ & 0.083 & 0.000 & 0.294 & -0.243 \\
X5: L. paracasei $(\mathrm{UFC} / \mathrm{mL})$ & 0.031 & -0.106 & -0.451 & $\mathbf{- 0 . 3 2 5}$ \\
X6: L. rhamnosus $(\mathrm{UFC} / \mathrm{mL})$ & -0.189 & 0.010 & -0.107 & -0.148 \\
X7: B. longum $(\mathrm{UFC} / \mathrm{mL})$ & 0.035 & 0.033 & 0.458 & 0.012 \\
\hline
\end{tabular}

*Variables in bold have a significant effect $(\mathrm{p}<0.10)$.

was the final number of CFU in the range of values studied. Mondragón-Bernal [16] evaluated the growth of probiotics in different concentrations of SHE, FOS, inoculum size, proportion of probiotics and temperature. The microorganisms evaluated (L. acidophilus, L. paracasei and B. longum) grew well in SHE. The author explained this fact by the variety of sugar substrates in SHE: sucrose, stachyose, raffinose, glucose and fructose, which can be utilized by the cells. On the other hand, this variety of sugars in SHE is not found in milk [14], which may make it a good prospect for the growth of probiotics.
The addition of FOS, despite being a substrate for probiotics and aiding in its growth, did not contribute to an increase in microbial population. It has been observed by other authors that usage of FOS by the microorganisms results in greater production of acetic and lactic acids, which quickly decreases the $\mathrm{pH}$ and consequently reduces microbial growth. High concentrations of FOS may negatively influence the final probiotic count [24].

From Table 5 it can be noted that these variables did not influence the $\mu_{\mathrm{x}}$ and $\Delta \mathrm{x}$ of Lactobacillus spp. For $B$. longum, the concentration of soy had a positive effect and the concentrations of FOS and L. paracasei an adverse effect.

Mondragón-Bernal [16] reported that SHE concentration had a positive significant effect on the growth of $B$. longumis, which is consistent with its ability to hydrolyze sugars such as raffinose and stachyose present in soybeans, due to its $\alpha$-galactosidase activity [8]. The concentration of $L$. paracasei negatively influenced the growth of $B$. longum. When $L$. paracasei and $B$. longum are grown together, L. paracasei is favoured, with a higher final count than when grown in monoculture [16].

For the following assays, the concentration of soy was fixed at $10 \%(\mathrm{w} / \mathrm{v})$ because it had a positive effect on $\mathrm{pH}$, and the initial concentration of FOS was maintained at the minimum value (3\%) since it showed a negative effect on the final number of $\mathrm{CFU}$ at higher concentrations. Probiotic concentrations did not influence the responses so that they were kept at the central point $\left(5.5 \times 10^{6} \mathrm{CFU} / \mathrm{mL}\right)$, except for $L$. paracasei which interfered in the growth of B. longum, and therefore was maintained at the lowest level $\left(1 \times 10^{6} \mathrm{CFU} / \mathrm{mL}\right)$. Temperature was fixed at $35^{\circ} \mathrm{C}$ because higher temperatures hindered the growth of the probiotics microrganisms. Under these conditions, new experiments were performed with the addition of sucrose, Streptococcus thermophilus and Lactobacillus delbrueckii subsp bulgaricus.

\subsection{Effect of the Addition of Sucrose and the Strains Streptococcus thermophilus and Lactobacillus delbrueckii subsp. bulgaricus on Fermentation}

In this set of assays, the changes in sucrose and FOS concentrations were determined, as well as the $\mathrm{pH}$ decrease during fermentation, while colony forming units and lactic and acetic acids were assessed at the end of the processes. Data obtained from these experiments is shown in Table 6.

As it can be observed, the initial $\mathrm{pH}$ of all fermentations is practically the same, and for the experiments in which sucrose was added (experiments 2, 6,7 and 8) it decreased faster because of a higher production of acids by the microorganisms. However, this does not mean that the 
Table 6. Data on the $\mathrm{pH}$, cells count $(\mathrm{CFU} / \mathrm{mL})$, FOS and acid concentration $(\mathrm{g} / \mathrm{L})$ in fermented SHE supplemented with Streptococcus thermophilus, Lactobacillus bulgaricus and sucrose.

\begin{tabular}{|c|c|c|c|c|c|c|c|c|c|}
\hline \multirow{3}{*}{ Experiments } & \multicolumn{3}{|c|}{$\mathrm{pH}$} & \multicolumn{3}{|c|}{ FCFU $(\log$ CFU/mL) } & \multicolumn{3}{|c|}{ Final concentration $(\mathrm{g} / \mathrm{L})$} \\
\hline & \multicolumn{3}{|c|}{ Fermentation time } & \multirow{2}{*}{ LC } & \multirow{2}{*}{$\mathrm{BL}$} & \multirow{2}{*}{$\mathrm{TC}$} & \multirow{2}{*}{ FOS } & \multirow{2}{*}{ LA } & \multirow{2}{*}{ AA } \\
\hline & $0 \mathrm{~h}$ & $4 \mathrm{~h}$ & $6 \mathrm{~h}$ & & & & & & \\
\hline 1 & 6.5 & 6.3 & 6.0 & 8.45 & 8.18 & 8.64 & $16.61^{3}$ & 7.0 & 0.43 \\
\hline 2 & 6.4 & 6.2 & 5.8 & 8.30 & 8.08 & 8.50 & 21.37 & 6.06 & 0.50 \\
\hline 3 & 6.4 & 6.3 & 6.0 & $8.34^{1}$ & 7.71 & 8.43 & $16.50^{3}$ & 6.90 & 0.43 \\
\hline 4 & 6.4 & 6.3 & 5.8 & 8.12 & $6.85^{2}$ & 8.14 & $17.20^{3}$ & 7.33 & 0.33 \\
\hline 5 & 6.4 & 6.3 & 5.8 & $8.19^{1}$ & $7.36^{2}$ & 8.25 & $15.59^{3}$ & 7.18 & 0.34 \\
\hline 6 & 6.4 & 6.1 & 5.6 & $8.18^{1}$ & 6.30 & 8.18 & 23.26 & 5.76 & 0.51 \\
\hline 7 & 6.4 & 6.1 & 5.1 & 7.85 & $7.58^{2}$ & 8.03 & 21.33 & 4.38 & 0.37 \\
\hline 8 & 6.4 & 6.2 & 5.4 & $7.92^{1}$ & $7.30^{2}$ & 8.09 & 24.87 & 3.90 & 0.36 \\
\hline
\end{tabular}

${ }^{*}$ LC: Lactobacillus spp., BL: Bifidobaterium logum, FCFU: Final CFU count, TC: Total CFU count, LA: lactic acid, AA: acetic acid, ${ }^{1}$ Lactobacillus bulgaricus count included; ${ }^{2}$ Streptococcus thermophilus count included; ${ }^{3}$ Experiments without addition of sucrose.

quality of the final product will worsen, because other characteristics, such as sensory acceptability and syneresis improved with sucrose addition, as reported by Mondragon-Bernal [11]. In fact, there was little variation in $\mathrm{pH}$ even with the addition of Streptococcus thermophilus and Lactobacillus bulgaricus, except for experiment 7 in which the $\mathrm{pH}$ dropped to 5.1, slightly lower the all others experiments.

At the end of all fermentations the number of probiotic CFU met the requirements [21], ranging from 8.03 to 8.45 $\log \mathrm{CFU} / \mathrm{mL}$. The addition of sucrose caused a slight decrease in the cell count of Lactobacillus spp., which may be due to an inhibition effect of sucrose, as reported by Mondragon-Bernal [11] concerning the growth of $L$. rhaminosus.

In the final cell count, it can be seen that experiment one (standard) presented the highest value, although there is no significant difference among assays, and all of met the minimum required level. Some studies reported that probiotics in co-culture with Lactobacillus bulgaricus and/or Streptococcus thermophilus indicated that it is possible to obtain a high quality final product with the growth of all strains $[5,6,25]$.

The FOS concentration in this work corresponds to the sum of kestose, nystose and 1-frutosilnistose concentrations. The FOS commercial product used is a hydrolyzate of inulin, containing oligosaccharides with molecular weight higher than those described above, so that their concentrations could not be quantified by a lack of standards, which means that the values shown in Table 6 do not represent the real total FOS, but instead an estimate. Therefore, the samples have in fact higher FOS levels than those shown in the table. However, according to AguiarOliveira and Maugeri [19], the methodology used enabled verification as to whether FOS were consumed or not and in which extension. Considering the data in Table 6, FOS consumption ranged from $16 \%$ to $50 \%$ of the initial amount. However the addition of sucrose helps to minimize this problem, as observed in experiment 8 where only $16 \%$ of FOS was consumed. The highest FOS consumption was observed in experiment 5 , in which $\mathrm{Lac}$ tobacillus bulgaric and Streptococcus thermophiles were supplemented but with no addition of sucrose. This can be expected because sucrose is generally more easily assimilated by microorganisms than FOS. In general, and in accordance with food regulations, a product with prebiotic claims should provide a minimum FOS in liquids foods [21], which depends on local regulations. According to Brazilian regulations, a beverage considered a source of prebiotics should provide at least $1.5 \mathrm{~g}$ of FOS. Therefore, since the final FOS concentration in this beverage ranged from about 15 to $25 \mathrm{~g} / \mathrm{L}$, the serving size should be at least of $100 \mathrm{ml}$ or less, depending on the concentration shown in Table 6 to meet regulations to be considered a source of prebiotics. It can be observed that there was a greater production of lactic acid compared to acetic acid, which is an ideal characteristic for this type of beverage, since the opposite can lead to poor taste characteristics. The production of acids in soy-based fermented beverages may vary according to the cultures used and substrates added, and may have higher concentrations ratios of acetic acid to lactic acid [23-25], so that the conditions used in this study are suitable for obtaining a final product with more pleasant taste. Experiments 1, 3, 4 and 5 present results similar to those observed by Mondragón-Bernal [16] who evaluated the production of a synbiotic soy-based beverage, and found a concentration of $7.09 \mathrm{~g} / \mathrm{L}$ of lactic acid at the end of the fermentation, with a slight production of 
acetic acid.

In general the highest lactic acid concentrations were obtained in experiments with higher growth of Lacto baccilus strains and in cultures with the addition of Streptococcus thermophilus (experiment 4). This is in agreement with results obtained by Wang et al. [25] who studied acid production by these strains separately, reporting that Streptococcus thermophilus produced greater concentrations of lactic acid.

\section{Conclusion}

Based on the results of this study it can be concluded that soy is a good substrate for the growth of probiotic microorganisms, and can be utilized in the production of fermented beverage at concentrations of about $10 \%(\mathrm{w} / \mathrm{v})$. Moreover, prebiotic compounds, such as fructooligosaccharides, are consumed by the microorganisms if added at the beginning of the fermentation, requiring that appropriate initial amounts are added for compensation in order for this product to be considered a source of prebiotics. However, the addition of sucrose aids to minimize FOS consumption, therefore decreasing the amount of FOS to be added for compensation. Probiotic microorganisms grow well in soy-based medium, leading to cell concentrations that meet regulations for products considered sources of probiotics. The inoculum did not exceed $5 \times$ $10^{6} \mathrm{CFU} / \mathrm{ml}$ to meet these regulations. The incubation temperature must be maintained at around $35^{\circ} \mathrm{C}$. Addition of Lactobacillus bulgaricus and Streptococcus thermophilus did not lead to real improvement of the final product considering the aspects studied in this work, therefore they should be excluded from this type of fermented beverage.

\section{Acknowledgements}

To the CNPq for its financial support and to the following companies that kindly donated the material utilized in this work: DANISCO for the probiotics, OLVEBRA for the soy extract, ORAFTI for the fructooligosaccharides and DOREMUS for the antifoaming agent.

\section{REFERENCES}

[1] M. E. Sanders, "Overview of Functional Foods: Emphasis on Probiotic Bacteria," International Dairy Journal, Vol. 8, No. 5, 1998, pp. 341-347. doi:10.1016/S0958-6946(98)00056-9

[2] M. B. Roberfroid, "Functional Food Concept and Its Application to Prebiotcs," Digestive and Liver Disease, Vol. 34, No. 2, 2002, pp. 105-110. doi:10.1016/S1590-8658(02)80176-1

[3] M. C. O. Hauly, R. H. B. Fuchs and S. H. PrudencioFerreira, "Suplementação de Iogurte de Soja com Frutooligossacarídeos: Características Probióticas e Aceitabi- lidade," Revista de Nutricao, Vol. 18, No. 5, 2005, pp. 613-622. doi:10.1590/S1415-52732005000500004

[4] T. M. Cunha, F. P. Castro, P. L. M. Barreto, H. D. Benedet and E. S. Prudêncio, "Avaliação Físico-Química, Microbiológica e Reológica de Bebida Láctea e Leite Fermentado Adicionados de Probióticos," Semina: Ciências Agrárias, Vol. 29, No. 1, 2008, pp. 103-116.

[5] O. N. Donkor, A. Henriksson, T. Vasiljevic and N. P. Shah, "Probiotic Strains as Starter Cultures Improve Angiotensin-Converting Enzyme Inhibitory Activity in Soy Yoghurt," Journal of Food Science, Vol. 70, 2005, pp. M375-M381. doi:10.1111/j.1365-2621.2005.tb11522.x

[6] E. R. Farnworth, I. Mainville, M. P. Desjardins, N. Gardner, I. Fliss and C. Champagne, "Growth of Probiotic Bacteria and Bifidobacteria in a Soy Yogurt Formulation," International Journal of Food Microbiology, Vol. 116, No. 1, 2007, pp. 174-181.

doi:10.1016/j.ijfoodmicro.2006.12.015

[7] A. S. Akalin, S. Gonç, G. UNal and S. Fenderya, "Effects of Fructooligosaccharide and Whey Protein Concentrate on the Viability of Starter Culture in Reduced-Fat Probiotic Yogurt During Storage," Journal of Food Science, Vol. 72, No. 7, 2007, pp. M222-M227. doi:10.1111/j.1750-3841.2007.00436.x

[8] S.-K. Yeo and M.-T. Liong, "Angiotensin I-Converting Enzyme Inhibitory Activity and Bioconversion of Isoflavones by Probiotics in Soymilk Supplemented with Prebiotics," International Journal of Food Sciences and Nutrition, Vol. 61, No. 2, 2010, pp. 161-181. doi:10.3109/09637480903348122

[9] C. L. L. Ferreira and E. Teshima, "Prebióticos, Estratégia Dietética para a Manutenção da Microbiota Colônica Desejável," Revista Biotecnologia Ciência \& Desenvolvimento, No. 16, 2000, pp. 22-25.

[10] S. Vij, S. Hati and D. Yadav, "Biofunctionality of Probiotic Soy Yoghurt," Food and Nutrition Sciences, Vol. 2, No. 5, 2011, pp. 502-509. doi:10.4236/fns.2011.25073

[11] O. L. Mondragón-Bernal, "Desenvolvimento de Alimento Simbiótico Fermentado de Soja," Ph.D. These, Universidade Estadual de Campinas, Faculdade de Engenharia de Alimentos, Campinas, 2009.

[12] O. L. Mondragón-Bernal, M. I. Rodrigues, H. M. A Bolini and F. Maugeri, "Optimization of Synbiotic Fermented Food from Hydrosoluble Soy Extract Applying Experimental Design and Sensory Analysis Techniques," Journal of Sensory Studies, Vol. 25, 2010, pp. 371-389. doi:10.1111/j.1745-459X.2009.00265.X

[13] F. Leroy and L. D. Vuyst, "Lactic Acid Bacteria as Functional Starter Cultures for the Food Fermentation Industry," Trends in Food Science \& Technology, Vol. 15, No. 2, 2004, pp. 67-78. doi:10.1016/j.tifs.2003.09.004

[14] C. P Champagne, J. Green-Johnson, Y. Raymond, J. Barrette and N. Buckley, "Selection of Probiotic Bacteria for the Fermentation of a Soy Beverage in Combination with Streptococcus thermophilus," Food Research International, Vol. 42, No. 5-6, 2009, pp. 612-621. doi:10.1016/j.foodres.2008.12.018

[15] R. P. S. Oliveira, P. Perego, A. Converti and M. N. Oliveira, "Growth and Acidification Performance of Pro- 
biotics in Pure Culture and Co-Culture with Streptococcus thermophilus: The Effect of Inulin," LWT-Food Science and Technology, Vol. 42, 2009, pp. 1015-1021.

[16] O. Mondragón-Bernal, "Desenvolvimento de Uma Bebida Fermentada a Partir de Extrato Hidrossolúvel de Soja, Contendo Agentes Prebióticos e Probióticos," Dissertação, Universidade Estadual de Campinas, Faculdade de Engenharia de Alimentos, Campinas, 2004.

[17] M. I. Rodrigues and A. F. Iemma, "Planejamento de Experimentos \& Otimização de Processos," 2nd Edition, Casa de Espírito Amigo Fraternidade Fé e Amor, Campinas, 2009.

[18] E. Aquarone, W. Borzani, W. Schmidell and U. A. Lima, "Biotecnologia Industrial: Biotecnologia na Produção de Alimentos," Vol. 4, Editora Edgard Blücher, São Paulo, 2001.

[19] E. Aguiar-Oliveira and F. Maugeri, "Characterization of the Immobilized Fructosyltranferase from Rhodotorula sp." International Journal of Food Engineering, Vol. 6, No. 3, 2010. doi:10.2202/1556-3758.1894

[20] A. G. Cruz, E. H. M. Walter, R. F. Cadena, J. A. F. Faria, H. M. A. Bolini, H. P. Pinheiro and A. S. Sant'ana, "Survival Analysis Methodology to Predict the Shelf-Life of Probiotic Flavored Yogurt," Food Research International,
Vol. 43, No. 5, 2010,pp. 1444-1448 doi:10.1016/j.foodres.2010.04.028

[21] ANVISA (Agência Nacional de Vigilância Sanitária), "Alimentos com Alegações de Propriedades Funcionais e ou de Saúde," Alegações de Propriedades Funcionais Aprovadas, 2008.

http://portal.anvisa.gov.br/wps/portal/anvisa/anvisa/home

[22] STATISTICA (Data Analysis Software System), "Programa de Computador," Versão 8.0, Stat-Soft, Inc., Tulsa, 2008. http://www.statsoft.com

[23] O. N. Donkor, S. L. I. Nilmini, P. Stolic, T. Vasiljevis and N. P. Shah, "Survival and Activity of Selected Probiotic Organisms in Set-Type Yoghurt during Cold Storage," International Dairy Journal, Vol. 17, No. 6, 2007, pp. 657-665. doi:10.1016/j.idairyj.2006.08.006

[24] S.-K. Yeo and M.-T. Liong, "Effect of Prebiotics on Viability and Growth Characteristics of Probiotics in Soymilk," Journal of the Science of Food and Agriculture, Vol. 90, No. 2, 2010, pp. 267-275. doi:10.1002/jsfa.3808

[25] Y. C. Wang, R. C. Yu, H. Y. Yang and C. C. Chou, "Sugar and Acid Contents in Soymilk Fermented with Lactic Acid Bacteria Alone or Simultaneously with Bifidobacteria," Food Microbiology, Vol. 20, No. 3, 2003, pp. 333338. doi:10.1016/S0740-0020(02)00125-9 